\title{
The Promise of Democracy: The Performative Social Contract, Pluralism, and Equality
}

\author{
Fred D'Agostino \\ The University of Queensland, Queensland, Australia \\ Email: f.dagostino@uq.edu.au
}

How to cite this paper: D'Agostino, F. (2020). The Promise of Democracy: The Performative Social Contract, Pluralism, and Equality. Open Journal of Political Science, 10, 302-318

https://doi.org/10.4236/ojps.2020.102019

Received: January 7, 2020

Accepted: March 28, 2020

Published: March 31, 2020

Copyright $\odot 2020$ by author(s) and Scientific Research Publishing Inc. This work is licensed under the Creative Commons Attribution International License (CC BY 4.0).

http://creativecommons.org/licenses/by/4.0/

(c) (i) Open Access

\begin{abstract}
In this paper, I will use methods associated primarily with applied ethics and economic theory to provide a philosophical demonstration, within the social contract tradition, of the importance for a democracy of the substantive equality of its citizens. The social contract is a familiar modality of contemporary democratic theorising in political philosophy. An unfamiliar but promising way of thinking about the social contract is via analogy with some features, and in particular, the extended temporality and, indeed, performativity, of "real-world" contracting. Real-world contractors agree to create the conditions, over a temporally-extended period, in which the terms of their agreement are materially realised. The question of their contract's ethical standing is not an $e x$ ante one-off, but is considered, rather, against a sequence of $e x$ post milestones. Ideally, as this sequence unfolds, the contractors (and others) will (performatively) summon into being the very conditions that embody the terms of the contract, thus progressively authorising it ex post facto. This approach draws on ideas, in jurisprudence, about relational contracts, and, in economics, about incomplete contracts. An approach of this general kind is well adapted to the circumstances of diversity in which all contemporary political theorising is placed and, arguably, gives a rationale for something like the modern social-democratic welfare state.
\end{abstract}

\section{Keywords}

Social Contract, Public Reason, Moral Pluralism, Informed Consent, Incomplete Contracts, Relational Contracts, Legitimacy, Stability, Hegemony

\section{Performative Contracts and Promissory Notes}

"We hold these truths ..." What did it mean, in the context of the Declaratory utterance, to hold as "self-evident" that "all men are created equal" when, plainly, no women, no enslaved men (and, indeed, no men without property) were 
considered equal (to free men) at the time these words were inscribed as a founding gesture of the American nation?

The notion of a "performative contract" enables us to make sense of this anomalous situation. On this account, a claim such as "all men are created equal" has to be understood as enunciating a project that aims to create the conditions in which this very claim can become (and hence be seen to be) true. In other words, the American Founders are not to be understood as describing an actually existing situation, but, rather, as issuing a promissory note: "We, and our successors, undertake to deliver a situation in which all citizens are equal in relevant respects. In order to deliver this situation, we will have to transform our social arrangements and, through that project, transform the society whose members are constitutionally the identical subjects/objects ("We, the people") of this promise. Whereas, at the time the promise is enunciated, subjects are, empirically, unequal in various ways (in some cases radically so, deprived even of basic citizenship rights that others enjoy in reasonable measure), they and their successors will gradually be transformed so that, in the future, citizens can stand before one another in substantive as well as formal political equality".

Of course, in saying this, I am not offering an account of what the Founders actually meant when they uttered through the Declaration and the Constitution. I wouldn't know about that; I am not a historian of ideas. Rather, I am offering a way of understanding, from our present situation, the potential of words like these to inspire projects, and to inspire demands that such projects actually be pursued. To put it another way, whatever the intentions of the Founders, and as Martin Luther King clearly saw, their words imply a promise that we can keep them and their successors to ${ }^{1}$.

On this account, the measure of the moral standing of a promissory or performative contract incorporating this stirring phrase is not something about the situation in which the phrase was enunciated (an ex ante perspective); it is, rather, something about the situation in which the terms of the implied contract are gradually and progressively delivered (an ex post perspective). We can't, on this account, evaluate the legitimacy of the United States as a democracy at or even near the time of the Declaration or the Constitution, but, rather, only retrospectively, say at the time the Fourteenth Amendment was enacted or Brown was decided or the Voting Rights Act was passed by Congress or ... We have a series of milestones, rather than a simple atemporal yes-or-no issue. Of course, we might conclude, indeed many will conclude, that the words are, even in this framework, hollow at and after the time of initial utterance-they may have enunciated a potential project, but the project was never initiated or, if initiated, ${ }^{1}$ As Gaus (2016: p. 12) reminded me King (1963) uses precisely the trope of the promissory note in the (relatively neglected) beginning passage of his famous "I have a dream" speech of 28 August 1963: "In a sense, we've come to our nation's capital to cash a check. When the architects of our Republic wrote the magnificent words of the Constitution and the Declaration of Independence, they were signing a promissory note to which every American was to fall heir. This note was a promise that all men-yes, black men as well as white men-would be guaranteed the unalienable rights of life, liberty and the pursuit of happiness. It is obvious today that America has defaulted on this promissory note insofar as her citizens of color are concerned". 
never realized to a significant enough extent to deliver the words, retrospectively, the kind of meaning that they could have had ${ }^{2}$.

Notwithstanding this caveat, this promissory approach has two considerable advantages in relation to more familiar argumentation. First of all, it shows us how to reason publicly to thick conceptions of democratic rights from a starting-point of ethical (and other forms of) pluralism, as I will try to show. Even individuals who radically disagree about "what is good" may be able, in democratic circumstances, to agree that each individual requires certain capacities to be equal before the law and, indeed, to take an equal part in self-government. Secondly, this approach enables us to connect contractualist reasoning with substantive egalitarian commitments to social-democratic institutions such as "the welfare state" 3 . Indeed, these points are connected. Citizens can, eventually, stand before one another as political equals only if, in the limit, each and every one of them has the moral and intellectual capacities of the citizen. And these capacities are themselves deliverances of institutional and cultural circumstances that have to be contrived, rather than simply assumed as natural concomitants of any system of social arrangements. We need universal education, health and well-being, freedom from fear and from economic insecurity, and so on in order to function as citizens in a democratic society of equals. We need, to be specific, Franklin Roosevelt's "Second Bill of Rights", as Sunstein (2004) has recently emphasized.

Finally, I offer this sketch, for a new approach to social contract thinking, as a contribution, as well, to our understanding of public reason. Certainly, in the past forty or so years, the social contract has been the most significant of the various approaches to public reason that can be distinguished (See D'Agostino, 1996: esp. ch. 4). To show different individuals that each has a reason to agree to the terms of some social contract is, in effect, to show that the terms of that contract satisfy the requirement of public reason (Quong, 2013): "that the moral or political rules that regulate our common life be, in some sense, justifiable or acceptable to all those persons over whom the rules purport to have authority".

The challenge which I accept on this occasion is to consider whether there is a version of social contract theory, and therefore an approach to public reason, ${ }^{2}$ Of course, this is too simple. There is a sense in which we can do an ex ante evalution of the terms of the social contract implied by the founding documents. We make that evaluation from some imagined, but morally privileged perspective, such as Rawls's notorious original position. And we can always, ex post, consider the various enactments and events of government, such as those I've mentioned, as potential milestones along a pathway of progressive materialisation of the ideal that we foreshadowed ex ante. So, while we can, in all likelihood, never plausibly claim to have established without a shadow of doubt or suspicion of dissent that some project has justified itself by its achievements, we can, and certainly do, measure its progress via these achievements towards the ideals that grounded it at the founding moment(s).

${ }^{3}$ In fact, this article has a complex provenance and it may be worth saying a few words about that. Originally commissioned as a keynote piece for a multi-year project, in Oxford, on The Social Contract Revisited, supported by the Foundation for Law, Justice and Society, it was later presented at a Macquarie University symposium on Articulations of Justice: Justice and Equality, supported by the IPSA Research Committee on Political Philosophy. On the former occasion, my task was to ground the welfare state in a contractualist framework; on the latter, to show the compatibility, given moral pluralism, of contractualism with a thick understanding of equality. 
which, in the face of significant irreducible pluralism about "the good" (as already recognized by Rawls) and, indeed, about the very standards that we use to evaluate claims about public reason (as I have argued on previous occasions), is compatible with a reasonably robust egalitarian framework for social interaction and, in particular, with the substantive, rather than merely formal, equality of citizens.

\section{What's the Problem with Social Contract Theory?}

In this section, I review recent work in social contract theory and arrive at the conclusion that there is a significant tension between two reasonable requirements for such a theory. In particular, the requirement that a social contract is not too closely tied to potentially corrupted values and beliefs is in tension with the requirement that citizens should be amenable to meeting the demands imposed by the contract. In Section 3, I show how to resolve this tension by modifying our understanding of the social contract as a theoretical device.

According to social contract theory, as embodied classically, for example, in the otherwise rather disparate works of Hobbes, Locke, Rousseau, and Kant and, more recently, in the work of John Rawls, James Buchanan and others, legitimacy of key social institutions, of the state itself, is to be assessed in terms of the acceptability of these institutions to all relevant parties, marked by the parties' collective consent (For a good overview of classical and recent social contract thinking, see Lessnoff, 1986). We contract with each other (or, on some interpretations, jointly with the sovereign) to create the conditions of legitimate social interaction and are thereafter morally bound to lend our support to maintaining those conditions, e.g. by obeying the law, paying taxes, participating in the political life of the community, and so on. Because the idea of contract is implicitly committed to the importance of a certain form of consent, such an approach has, as Thomas Nagel has notably pointed out, the advantage of grounding authority in freedom. As he puts it (1991: p. 36):

The search for legitimacy can be thought of as an attempt to realize some of the value of voluntary participation, in a system of institutions that is unavoidably compulsory ... To show that ... all [participants] have sufficient reason to accept ... [a regime] is as close as we can come to making this involuntary condition voluntary.

Of course, not all collectively accepted arrangements, at whatever scale we might find them, are really legitimate and hence invite compliance, and that is what social contract theory has been concerned with for the past 400 years or so-identifying the conditions under which collective consent would confer legitimacy and determining what sorts of social arrangements might be legitimated through these means. Not surprisingly, given their different starting-points, very different social arrangements have been recommended by these theorists-ranging from the authoritarianism of Hobbes to the welfarist but still broadly liberal (as opposed to social-democratic) conception of Rawls. 
Two ideas, one from applied ethics and one from contract law, may clarify some of the issues about the relation, which is fundamental for social contract theory, between collective consent and legitimacy ${ }^{4}$.

From applied ethics (e.g. Faden and Beauchamp, 1986), we can borrow (and collectivize) the idea, vital in conferring legitimacy in experimental and/or biomedical contexts, of free and informed consent. A subject's participation in an experiment, a patient's submission to a particular treatment regime, is legitimate, we say, when she has given her free and informed consent; her participation is otherwise, though defeasibly, suspect. Theory and casuistical readings of "hard cases" have helped applied ethicists to identify a number of disqualifying conditions, which can be crudely summarized under three main headings:

1) misinformation: The subject's consent, even if given, does not legitimate her participation (in the experiment or medical procedure) if she was misinformed about the nature of the situation;

2) coercion: The subject's consent, even if given, does not legitimate her participation if she was coerced or suborned (e.g. through inappropriate inducements);

3) incapacity: The subject's consent, even if given, does not legitimate her participation if she was either temporarily or permanently incapacitated in some way bearing on her ability to give ethically meaningful consent.

This third disqualifying condition provides a natural link to the idea, from contract law (Smith, 2000: ch. 17), of contractual capacity. Legally, an individual's agreement to its terms might not contribute to the legitimation of a mundane commercial contract if, for example, she lacked the capacities to understand those terms, e.g. because of a cognitive or other decision-relevant disability or deficit. In some jurisdictions, individuals in certain classes, e.g. minors, are deemed, whatever the facts in their particular cases, to be contractually incapacitated; any contract which such an individual agrees to is, e.g. in the case of minors, voidable through simple disaffirmation.

It is natural to extend these ideas (of contractual capacity and free and informed consent) to social contract thinking. We might say, then, that those social arrangements, e.g. among citizens to constitute a state, are legitimated by the collective consent of the parties when the parties, individually, are well-informed, uncoerced, and have and express through their consent what I will call a social-contractual capacity. To put it another way, if some party to a proposed so${ }^{4}$ The notion of legitimacy is an internally complex one and in several ways. When I refer here to the legitimacy of certain constitutional arrangements, of the basic structure of society, in Rawls's terminology, I mean their acceptability from the point of view of public reason or as conclusions of appropriately constrained social contracting. That some institution is legitimate in this sense may carry other implications, as already indicated-e.g. a duty to perform in accordance with its requirements. The judgment that an institution is legitimate is itself complex, and may encompass issues both about what should be acceptable from the point of view of public reason and what commands the ready assent of those whose compliance will be necessary to sustain it. On these matters, see D’Agostino, 2005.

${ }^{5}$ I was immensely heartened, for I admire her work, to discover that Yeatman (1997: p. 40) had used, years earlier, much the same phrase with, I believe, much the same meaning. 
cial contract is ignorant, deceived, coerced, suborned, befuddled, incontinent, or the like, then her consent to the proposed terms of that contract is of no more significance in legitimating those terms than it would be in binding her to the terms of some more mundane contract (And similarly, though not perhaps as vividly, for dissent. Someone whose dissent is misinformed or coerced or who substantially lacks a capacity to provide ethically meaningful dissent may, again, be of no significance in de-legitimating the terms of some otherwise acceptable social contract. This is, perhaps, a feature which distinguishes a social from an ordinary contract).

These observations are certainly banal, but the ethical significance of free and informed agreement among parties possessing and exercising an unimpaired capacity to contract explains, I believe, the elaboration, historically, of social contract theory along its familiar trajectory.

- from actual accounts-what legitimates social arrangements is what stakeholders did, as a matter of fact, agree to;

- through hypothetical accounts-what legitimates social arrangements is what stakeholders would agree to if actually asked;

- towards an ideal account-what legitimates social arrangements is what stakeholders ought to agree to, i.e. what they themselves would agree to if they were sufficiently well- and relevantly-informed, uncoerced, and clear thinking.

This trajectory in the elaboration of social contract thinking simply reflects, on my account, an increasingly sophisticated understanding of the relationship between collective consent and legitimacy. Indeed, it is through this trajectory that the social contract tradition makes contact with the public reason tradition to which, as a historical matter, it gives rise. Whereas, on actualist and hypotheticalist accounts, the consent of an individual to a proposal need not signal that that individual has a reason to endorse that proposal, the demands of contractualism and of public reason come together, as it were, for the idealist account.

In any event, this trajectory recognizes that some actual and indeed some hypothetical agreements fail to confer legitimacy insofar as they are obtained (or are modelled as obtainable) from stakeholders suffering from one or more of the disqualifying conditions we have identified-i.e., misinformation, coercion, incapacity. Indeed, we can say more, and be more concrete and specific. When stakeholders are misinformed, perhaps because of propaganda or because of the persistent effects of ideology, we may have consent but what the consent marks is not legitimacy, but, rather, hegemony in the specifically Gramscian sense (Gramsci, 1971); we have, in other words, "spontaneous consensus" encompassing both dominating and dominated groups, but its "spontaneity" is an artefact, not a marker of legitimacy and certainly not a moral backing for the exercise of authority.

Symmetrically, we may have, indeed characteristically will have, that, when 
some stakeholders are incapacitated, they will not consent to arrangements from which they might benefit and to which they might consent if they were able to think more clearly and constructively about their situation. On an earlier occasion (D'Agostino, 1982), I have discussed the significance of this for mental health care. I mention, below, the issue of "adaptive preferences", where individuals may acquire preferences that adapt them to oppressive circumstances. Someone with preferences of this kind may well dissent from rather than consenting to social arrangements from which she might benefit, especially relative to the circumstances that she currently inhabits. And her dissent may be no more meaningful, when judging the legitimacy of the proposed social arrangements, than the consent is of stakeholders subject to hegemony. In both cases, we need to idealize away from their concrete circumstances to construct a contractual basis for social arrangements with any claim to moral legitimacy.

Of course, it is not cost-free, either theoretically or politically, to move from actual to ideal consent, however appropriate this might be as a means of addressing issues of hegemony and incapacity. This is a point to which John Rawls, with his pragmatist orientation (see D'Agostino, 2004a), gave a great deal of attention. Let me explain.

When we devise an ideal contract, we substitute, for the actual consent of the stakeholders, the consent of their idealized surrogates, or, in other words, of imagined individuals who are freer of coercion and subornation, better and/or more relevantly informed, and clearer thinking; who are, we might hope, at some distance from the effects of ideology and hegemony and who can understand their principals' real interests clearly and reason effectively about how to secure those interests. The terms of the social contract are determined, then, by what such surrogates would (have reason to) agree to (see D’Agostino, 2008). But we expect these terms to bind the behaviour of the stakeholders themselves, with (relative to the imagined surrogates) all their empirical deficiencies of freedom, information, and capacity. The difficulty is: The more different the stakeholders from their surrogates, the less motivational purchase will surrogates' reasoning and conclusions have on the stakeholders and, accordingly and ironically in view of the Gramscian terminology, the less spontaneous (particularly undeceived, uncoerced) uptake will there be by stakeholders of the terms of the contract which is meant to be binding on them (See D'Agostino, 1996). This is what Rawls (1972) called "the problem of stability", which he made heroic and repeated attempts to address, especially in the much-neglected Part III of his masterwork $A$ Theory of Justice.

The problem is neither trivial nor purely theoretical. Nor is the problem trivial, by the way, of explaining how it is that we are to conceptualize surrogates who are supposed to be free( $r$ ) of the effects of ideology, when we are, by hypothesis, potentially affected ourselves by ideological and/or hegemonic formations. I return to this conundrum below. In the meantime, let us consider why the problem of stability is indeed a problem. 
Surrogates are portrayed by social contract theorists as reasoning, inter alia, about the norms and institutions that are morally appropriate as a basis for collective life. Suppose that they consent, collectively, to some particular rule or institution. A further important test of the feasibility of this rule or institution is the degree to which those whose lives it will affect behave in ways that stabilize the rule or institution so that it can deliver the benefits of its implementation. (Economists (e.g. Hurwicz, 1972) call this "incentive compatibility"). The most obvious case involves what philosophers (e.g. Mellema, 1991) call supererogation-or morally heroic conduct. If some rule or institution could not persist without supererogatory performances by numerous personnel and other stakeholders, then it probably will not persist. But, if it does not persist, then it does not deliver to affected parties whatever benefits figure among the grounds for its legitimacy, whatever benefits, in other words, might have figured as reasons for their surrogates' (idealized) consent. Accordingly, the recommendation to adopt such a norm or to develop and support such an institution would be self-defeating, and any contractualist reasoning which led to the proposal to implement such a norm or institution would therefore be defective. (This is, of course, another way of representing some aspects of Rawls's famous method of reflective equilibration).

Obviously, there is a spectrum of possibilities here, and the case of supererogatory norms lies close to one end of that spectrum. Still, there are, undoubtedly, a great many more mundane cases where what might appear to be legitimate cannot be institutionally sustained and, hence, probably ought not to have been consented to as legitimate in the first place (so long as we consider uptake crucial for some judgment about all-things-considered legitimacy).

While we need to get some distance from stakeholders' actual beliefs, values, and courses of reasoning-as a bulwark against ideology and hegemony-we can't get too far from these attitudes and capacities or we risk a form of puerile utopianism (e.g. Nagel, 1991: p. 30)-recommending what cannot actually be effected.

This may seem like a politically conservative conclusion to have come to. We seem to be led back, by the issue of stability, to precisely the actualist (or at best hypotheticalist) forms of contract thinking which we have already rejected (and thus, by implication, away from the point of contact between public reason and social contract traditions). This is not a good place to arrive. For one thing, it is not clear, in pluralist settings, to introduce another variable in the equation, that there can be any non-empty consensus (of the kinds that legitimate according to social contract theory) when we deal with people as they actually are (as both narrow actualist and hypotheticalist versions of contract theory do). Consider, for example, even a small moderately diverse sample of the populations of any of the great North Atlantic democracies. These individuals are likely to differ across a great many attitudes, beliefs, values, styles of thinking, and issues. One reason for the move to idealized contracts is the issue of hegemony, but another is the 
issue of diversity: contemporary populations are too diverse for it to be plausible to imagine their collective assent to anything of much substance (see D'Agostino, 2004b). Under pluralist circumstances, we seem to be driven back towards a normatively relatively empty libertarianism or anarchism. (This, certainly, is a concern articulated by the RC31 conference organizers (see note 3 above) and remains a worry for many public reason and social contract thinkers: "Does the moral pluralism of modern societies of itself impose a thin, formal conception of the good society? Does modern pluralism directly preclude some more substantive normative basis for politics?").

We find ourselves, apparently, pressed in from several sides. On the one hand, we can't trust the agreement we might sometimes get from surveying or eliciting the actual attitudes of concrete stakeholders. Their consent, where it exists, may be tainted by misinformation, subornation, and the like. On the other hand, we can't count on such agreement anyway. What one person might consent to another person might dissent from, across a great range of issues. Indeed, the two points are related. We might, given pluralist arguments supporting diversity of attitudes, suspect by default any substantial consensus of judgment; it can, we might imagine, only have been rigged and therefore cannot be trusted to legitimate. (This is what Rawls thought about the possibility of deriving a theory of right from a theory of the good).

I think, though, that there is a way out of this nest of difficulties. It involves, in my view, being more imaginative in the way we analogize from the mundane commercial contract to the social contract.

\section{What Is a Contract? An Alternative Conception}

What is a contract? It is an agreement to exchange. Contracts, however, are typically enacted over time. A contract, in other words, is not an event, but rather a process. We negotiate a contract and then sign it, marking our joint consent, but, once we have consented, the work of enacting the contract remains to be done. We still have to fulfill its terms, and this may take place in stages and progressively. Indeed, considerable time may elapse between signing the contract and fulfilling its terms-between, say, agreeing that an engineering firm will design and construct an ore refining plant for a mining company and the actual hand-over, fulfilling the contract, of the completed plant. Along the way, there will be milestones and there will, of course, be changes to circumstances, unforeseen in the negotiation phases of the contractual process, that may require re-negotiation or, at least, forbearance on the part of one or both parties to the contract about the way in which the process unfolds. (I was delighted to discover the work of Ian Macneil (2001), where I find some welcome echoes of what seemed, at the time I first wrote, a rather extravagant reinterpretation of the contract idea in political philosophy).

All this is absolutely typical in relation to mundane contracts (even if one doesn't accept the relational account of the contract associated with Macneil). 
Indeed, we might even say that the very function of or necessity for contracting is to guide the on-going behaviour and to regulate the expectations of the parties about a process that unfolds over time, often over long periods of time. Transactions or exchanges that can occur more or less instantaneously hardly need to be governed by a formally negotiated contract and often are not.

What has this to do with the social contract? I am suggesting that we look at social contracting in the same way. Not as an instantaneous event, but, rather, as a process. On this account, what happens is that surrogates for stakeholders (are imagined, theoretically, to) negotiate and consent to a contract whose terms specify a project to deliver certain outcomes. On this interpretation, we need to recognize, surely even more obviously in the case of the social contract than in mundane commercial circumstances, that the project may be a temporally extended one in which the outcomes are only progressively approximated, rather than being delivered instantaneously and in full measure.

To simplify the picture a little, I propose that there are, properly, two moments of legitimation in contractualist models. Adapting some terminology from economics (Akerlof and Dickens, 1982), we can label these the ex ante and ex post perspectives. Ex ante, stakeholders' surrogates (are imagined to) negotiate and consent to a contract to develop, as a large-scale and long-duration collective social project, the basic structure of society, as Rawls calls it. (This is what the Founders did, on my account, when they said, inter alia, "We hold these truths ...") Whether the initial agreement to institute this project was a sound one can, however, only really be judged ex post, when it becomes clear, for example, whether the basic structure, as specified, has indeed been developed, or, more realistically, whether its fundamental elements are progressively being realized over reasonable periods of time. We can also better judge ex post whether, if the terms of the contract were fulfilled, it was, in fact, worthwhile that this has happened. The contract, on this account, becomes a promissory note, issued by surrogates and redeemable by stakeholders or their successors, offering, in particular, the prospects of a certain kind of future. It is therefore judged, crucially, on what kind of future a process guided by its tenets actually does deliver to the stakeholders ${ }^{6}$.

On this model, we need ex ante idealization because, ex ante, the stakeholders themselves might either be too diverse to agree to anything or, perhaps, inadequately informed or insufficiently free of coercion or subornation or ideological influences. Their consent-and their dissent as well-is not really meaningful in assessing even the prospects of the proposed contract and its specific terms; only ${ }^{6}$ Since writing these words, I have found some echoes in the work of Derrida (1989-1990: pp. 991 and 993) of the idea I am trying to articulate here. I like, in particular, though I could hardly claim fully to have absorbed its subtleties, his idea that, in the foundations of some ethico-legal framework, "the grammatical category of the future anterior all too well resembles a modification of the present to describe the violence [or perhaps unfinished business] in progress". He continues: “A 'successful' revolution, the successful foundation of a state (in somewhat the same sense that one speaks of a felicitous performative speech act) will produce après coup what it was destined in advance to produce ...”. 
idealized surrogates can be understood as having the requisite capacities and as inhabiting an appropriate situation. But ex ante agreement of surrogates isn't enough because, as we've seen, it's not they, but, rather, the stakeholders they represent who will actually have to develop the social arrangements contractually specified by the surrogates. If the stakeholders are to be recruited to the project of developing these arrangements progressively over lengthy periods of time, then 1) the prospects must be reasonably appealing, but, more importantly, 2) over time, progress against the benchmarks in the initial contract must occur and must be seen to occur. The episodic ex post endorsement of the stakeholders themselves is therefore a crucial element of the social contract, just as the periodic ex post acquiescence of mundane contractors is vital in sustaining their relations over lengthy progressive implementation of the terms of their agreements with each other. And, by the way, just as in mundane cases, it cannot be ruled out, and indeed is to be expected, that ex post perspectives will sometimes lead to renegotiation of the social contract, to reflect the evolving sensibility of the stakeholders. On this account, "we, the people" were right to claim our equality as self-evident only if, over a period of time, we have managed to make our world a more equal one in some relevant sense. If the promise is realized, or if progress is made towards its realization, then to that extent the demands imposed by the institutions that underpin its realization are legitimate and are likely to be seen as such.

Of course, the actual history of such a great project of equality is likely to be characterized by episodes of varying character in relation to the underlying ideal. Historically, progress is fitful, long stretches of "normal politics" punctuated by intense episodes of rapid change, as in Ackerman's (1993) model of "dualist democracy".

\section{Elaborating the Alternative Conceptualization}

Of course, we have residual questions. Why should stakeholders themselves endorse, even ex post, social arrangements that they might not have consented to ex ante? And why should their ex post endorsement, should it be obtained, be legitimating, when their ex ante consent, could we have obtained it, might not have been legitimating?

The answers to these questions are related, in fact. Stakeholders will endorse ex post arrangements they might not have consented to ex ante when, as a result of the contracted-for institutions being progressively implemented, stakeholders are themselves progressively transformed in various relevant ways-specifically, when they become, empirically, progressively more like their surrogates than they were antecedently. (This is a Rousseauvian element in my account.) And their episodic ex post endorsement will be binding precisely to the extent to which this transformation occurs.

In this regard, it is important to distinguish the general from a specific case. The specific case I have in mind is, of course, that in which the promise is one to 
enact a democratic society of equals. And, in that specific case, the reason the ex post endorsement of stakeholders is binding, ethically, is, of course, because they will, if the promise has been redeemed, have become freer, better-informed, and more completely endowed with the social-contractual capacity. They will, in short, become beings whose collective consent does confer legitimacy and is ethically binding. (I will return shortly to the general case).

This, of course, is what Rawls was after in relation to the original position and the stabilization of its deliverances. Idealized surrogates for you and me contract for us and, progressively implementing the terms of this contract, we become, over time, more and more like our idealized surrogates and, hence, more and more stabilized in our commitment to these terms-our contracted-for social arrangements become self-sustaining precisely because or insofar as they are sustained by beings who find it comfortable, ethically and otherwise, to do what needs to be done to sustain them, whatever they or their predecessors might have felt or thought initially. (I will return to the question: Why should a diverse collection of stakeholders agree to anything other than trivialities?).

This, then, is the way we should understand the stirring phrases of the Declaration and the Constitution, largely false or at least hollow if interpreted literally at the time of their composition. They are promises that have to be redeemed by the implementation of the projects they outline. To say that all are created equal even as some struggled (literally) against their chains is, on one reading, hypocrisy, but it is, on another reading, a promise articulating a project. The institutions built on this promise, might, in other words, be legitimated ex post and will be if the stirring phrases, e.g. announcing equality under the law, become truer and less hollow, e.g. with the incorporation into the Constitution of the Fourteenth Amendment, or with the Supreme Court decision in Brown. For, in that case, the stakeholders and their successors are transformed into the sorts of democratic political subjects whose consent really does serve to legitimate the institutions that made them ${ }^{7}$. And, in the meantime, they may be sustained by the promise that has yet to be realized. It becomes available as rhetoric and as inspiration, even to those who are currently denied its deliverances. It charts their course as well as the redemptive project of the community as a whole.

\section{Refining the Contract}

All this suggests an interesting question and a difficulty, and they are in fact related.

The difficulty has to do with "adaptive preferences" (Elster, 1983), or, at least, with an extension or generalization of that idea to encompass other morally-relevant attitudes such as beliefs, values, dispositions, and the like. We can put the matter starkly, and trot out, for convenience, the usual bogies. You might ${ }^{7}$ This would seem to make my approach a broadly republican one. See for example Schwarzmantel, 2006: p. 214: "The hope of the republican perspective is that a republican political system would be itself engaged in a virtuous circle. Its practices and institutions will induce in its citizens those attitudes that in turn sustain the republic and its democratic practices". 
say: It's all very well to say that the redemption, over the course of 200 years, of the egalitarian promise of the American Constitution (supposing you think that promise has been redeemed) legitimates ex post what some at least certainly never consented to ex ante. But getting ex post endorsement of some regime whose effects include the recruitment and induction into its disciplines of the stakeholders is, as we know all too well, all too easy to ensure. People adapt their attitudes to cohere with the activities they are otherwise bound to be part of. (This is a form, then, of dissonance reduction (Festinger, 1957)).

The model of promissory legitimacy cannot be the right one-and here the bogies pop up through the trap-door-because, if it were, it might provide a basis for legitimating the National Socialist regime of Hitler Germany, which, after all, formed its stakeholders so that the terms of its institutional arrangements were, arguably, acceptable ex post to them. (Here I engage with the general case that I mentioned earlier. As it will appear, the special case actually is or at least exhausts the general case, and issues of the legitimacy of Hitler Germany have an easy solution within the framework of promissory contracting. But this depends on what might almost seem like a trick and I am not quite ready to spring it).

That promissory contracting might legitimate the institutions of Hitler Germany is, in fact, an instance of the important worry from which we started-that contractual models may not get us far enough away from ideological/hegemonic starting-points to be genuinely legitimating.

The interesting question is related to this difficulty, and it goes as follows. What should we be focusing on when we consider the promissory contract? Is it just the bare fact of ex post endorsement or consent? Or is it, instead, something a bit subtler? It is, in fact, something a bit subtler. And this something subtler enables us to distinguish the specious legitimation of Hitler Germany from, say, the genuine if still radically incomplete legitimation of American constitutional lawmaking. Some ex post consent does and some ex post consent does not legitimate promissory contracts. That consent does legitimate which reflects a wellinformed, uncoerced, and reasonable/rational citizenry, even if it depends on the formation of such a citizenry by institutional projects to which there was inadequate ex ante consent by the stakeholders themselves. It might be reasonable to argue that American constitutional history shows a progressive redemption of such a promise. It is not reasonable to argue that the shorter history of Hitler Germany shows a progressive realization of this kind of promise. The promise of Nazi ideology might have been progressively realized, but not the kind of promise that lies at the heart of all (specifically promissory) contract thinking-namely, that the stakeholders be made, if they are not already, fit to issue legitimating consent, that they be endowed, in short, with an adequate social-contractual capacity.

What we can see, then, is that there are two moves in this model of legitimation-the contractual move, and the promissory move. Without the promissory move, we don't know how to legitimate in the face of diversity and/or lack of so- 
cial-contractual capacity. Without the contractual move, though, anything might have ex post legitimacy (because of adaptation of attitudes to institutions). With this move, however, only that can be legitimated, using the promissory mechanism, which delivers to the stakeholders the social-contractual capacities on which the legitimacy of their agreements in fact rests. There is, in other words, only what I have called "the special case" when it comes to promissory contracting. The only kind of promissory contract is unavoidably one to deliver a democratic society of equals under the law.

\section{The Social Contract and a Thick Conception of Social-Democratic Equality}

But now we can see the relevance of social contract thinking to a thick and substantive conception of equality among citizens. No social contract legitimates unless it delivers, for those who do not already have it, the social-contractual capacities on which the legitimacy of its terms in fact depends. This means that it is the responsibility of the contractually-instituted state to ensure that those social circumstances are progressively realized in which all those capacities that are directly involved in public reasoning about the terms of a just social arrangement are themselves progressively delivered to its citizens. Otherwise, it does not fulfill its promise and hence attain or progressively approximate ex post legitimacy. And all those capacities that are functional prerequisites for these primary contractual capacities must also be progressively delivered for legitimacy to be progressively realized. And this means, clearly, a thick substantive equality of citizens.

We need to reason well and have choice-relevant information to give validating ex post consent to a system of social arrangements. Accordingly, those arrangements ought to ensure that these capacities are sustained and nurtured. What this means in relation to substantive equality of citizens is partly an empirical matter, but the cartoon version is simple enough. Reasoning well means understanding the issues and being free to deliberate about them-or, shall we say?, free from the fear which inhibits deliberation, from the anxieties which are born of poverty and ignorance and of the narrowness of vision which these deprivations enforce. This, then, is the key, and, as I said before, the link between democratic egalitarianism and contractualism. The social contract is a project and can be enacted, over time, only in circumstances in which the substantive well-being of stakeholders is enhanced to support the progressive realization of their social-contractual capacity. All this was clearly understood by Franklin Roosevelt, whose so-called "second Bill of Rights" was articulated, near the end of the Second World War, when he said, in the State of the Union address for 1944 (Rosenman, 1950: p. 40), and in terms that are as cogent now as they were then, that "[w]e cannot be content, no matter how high [our] general standard of living may be, if some fraction of our people-whether it be one-third or one-fifth or one-tenth-is ill-fed, ill-clothed, ill-housed, and insecure". Indeed, 
we cannot. In so far as their fate is of that kind, they are at risk of failing in the social-contractual capacity that we need them to deploy for our common good. (The argument, at this point, is of course partly empirical. What are the cultural and institutional prerequisites for a widespread equality of social contractual capacity among a large and diverse population? My assumption is that these prerequisites include substantive equality of opportunity in relation to education, health, and the like, but this is, of course, an empirically-testable assumption and I do not defend it here). And we fail them, and our democratic heritage and therefore ourselves, if we leave them in such a state. This, certainly, is the view of what King and Waldron (1988: pp. 425-426) call "the great theorists of citizenship", namely, that "one of the strongest arguments in favour of [an egalitarian] welfare provision is the empirical one that securing the basic social standards does in fact promote the existence and exercise of other citizenship rights." Or, as they conclude, "if we take the idea of universal suffrage seriously, then we should not be content simply to give everyone a vote; we should set about the task of giving them economic security, which ... is the necessary precondition for good citizenship".

By the way, these considerations enable us to answer the question, in a non-trivial way I believe, of what a highly diverse collection of stakeholders could in fact agree to. They could, I hold, agree to be transformed, as far as that is necessary, into competent social contractors. And that means, in effect, that they agree to quite a lot of social and personal transformation, of the kinds necessary for that abstract goal to be realized and, hence, to quite a thickly described set of social arrangements underpinning that sort of transformation-to universal education, adequate provisions for health and well-being, media freedom, and so on.

Finally, I said, earlier, that I would return to the question of how we could, ex ante, even imagine the idealized surrogates that we substitute for the stakeholders in the first moment of contractual reasoning. If our empirical attitudes are, or at least could be, adapted to our ideological circumstances, there will be limits, surely, to how thoroughly we can abstract from or, in Rawls's terminology, "veil" those circumstances and, accordingly, to how much critical purchase we can get on them. In fact, the two-stage, promissory contractualism that I am articulating shows the way forward here as well. It suggests to borrow some now rather dated terminology, that we will boot-strap our way, gradually but progressively, out of the ideological mire which we inhabit. As others have pointed out (e.g. Walzer, 1987), even ideology likes to cast its pronouncements in ethical and specifically universalizing terms. This, certainly, is what the Founders did when they articulated the idea of "self-evident equality". This gives us some leverage even from within a rather thorough-going ideological structure. We use that leverage to get a bit of distance from the ideology. This establishes a new starting point for a progressive and long-term project. From there, we can ascend still further. The key, as before, is in recognizing that contracts are 
processes not events and that, as enacted over time, they can reach outcomes that couldn't even have been anticipated-which weren't, perhaps, even imaginable - at the time they were initiated. (Who among the Founders was imagining Brown or anything like it?).

\section{Conclusion}

The innovation of this paper is to use the notion of a promissory contract as a device through which competing reasonable demands on social contracts might be successfully mediated. The tension between the requirement to avoid hegemony and that to secure motivational uptake of the contract's deliverances is dissolved by seeing how stakeholders can bind themselves to a promise that transforms them and their successors into the sorts of beings for whom what is required for justice and equity in a democratic setting is what is also desired by them. More importantly, this argument also provides a basis for asserting that a thick conception of democratic equality is demanded for the legitimacy of our social arrangements. For the legitimacy of those arrangements depends on the transformation of citizens into the sorts of beings whose consent legitimates. And the transformational project depends on the establishment of institutions and norms (familiar democratic ones) that support the substantive equality of citizens as a means to their availability as ex post legitimators of the social arrangements that form them. It is to these citizens that the demands of public reason are to be addressed. It is to create the conditions in which public reasoning can be efficacious that the promissory note, announcing the project of producing such citizens, is issued. Public reason need not peter out into a substantively empty philosophical anarchism or libertarianism. It can sustain a substantive conception of equality. For that is something that individuals fit to be citizens will agree on, and will have reason to agree on, ex post.

\section{Conflicts of Interest}

The author declares no conflicts of interest regarding the publication of this paper.

\section{References}

Ackerman, B. (1993). We the People, Volume 1: Foundations. Cambridge, MA: Belknap Press.

Akerlof, G. A., \& Dickens, W. T. (1982). The Economic Consequences of Cognitive Dissonance. American Economic Review, 72, 307-319.

D’Agostino, F. (1982). Mill, Paternalism and Psychiatry. Australasian Journal of Philosophy, 60, 319-330. https://doi.org/10.1080/00048408212340721

D’Agostino, F. (1996). Free Public Reason. New York: Oxford University Press.

D’Agostino, F. (2004a). The Legacies of John Rawls. Journal of Moral Philosophy, 1, 349-365. https://doi.org/10.1177/174046810400100308

D’Agostino, F. (2004b). Pluralism and Liberalism. In G. Gaus, \& C. Kukathas (Eds.), Handbook of Political Theory (pp. 239-249). London: Sage. 
https://doi.org/10.4135/9781848608139.n18

D’Agostino, F. (2005). Legitimacy in a Pluralist Context. In G. Young, \& G. Maddox (Eds.), Legitimation and the State (pp. 15-29). Armidale: Kardooair Press.

D’Agostino, F. (2008). Original Position. In E. Zalta, \& E. Hammer (Eds.), The Stanford Encyclopedia of Philosophy. Stanford, CA: Center for the Study of Language and Information. http://plato.stanford.edu/archives/fall2008/entries/original-position

Derrida, J. (1989-1990). Force of Law: The Mystical Foundation of Authority. Cardozo Law Review, 11, 920-1029.

Elster, J. (1983). See Sour Grapes: Studies in the Subversion of Rationality. Cambridge: Cambridge University Press. https://doi.org/10.1017/CBO9781139171694

Faden, R., \& Beauchamp, T. L. (1986). A History and Theory of Informed Consent. Oxford: Oxford University Press.

Festinger, L. (1957). A Theory of Cognitive Dissonance. Stanford, CA: Stanford University Press.

Gaus, G. F. (2016). The Tyranny of the Ideal. Princeton, NJ: Princeton University Press.

Gramsci, A. (1971). Selections from the Prison Notebooks. London: Lawrence \& Wishart.

Hurwicz, L. (1972). On Informationally Decentralized Systems. In R. Radner, \& C. B. McGuire (Eds.), Decision and Organization: A Volume in Honor of Jacob Marschak (pp. 297-336). Amsterdam: North-Holland.

King, D., \& Waldron, J. (1988). Citizenship, Social Citizenship and the Defence of Welfare Provision. British Journal of Political Science, 18, 415-443. https://doi.org/10.1017/S0007123400005202

King, M. L. (1963). I Have a Dream. https://www.archives.gov/press/exhibits/dream-speech.pdf

Lessnoff, M. (1986). Social Contract. London: Macmillan. https://doi.org/10.1007/978-1-349-18409-5

Macneil, I. (2001). The Relational Theory of Contract. London: Sweet \& Maxwell.

Mellema, G. (1991). Beyond the Call of Duty. New York: State University of New York Press.

Nagel, T. (1991). Equality and Partiality. Oxford: Oxford University Press.

Quong, J. (2013). Public Reason. In E. Zalta, \& E. Hammer (Eds.), The Stanford Encyclopedia of Philosophy. Stanford, CA: Center for the Study of Language and Information. http://plato.stanford.edu/entries/public-reason

Rawls, J. (1972). A Theory of Justice. Oxford: Oxford University Press.

Rosenman, S. (1950). The Public Papers and Addresses of Franklin D. Roosevelt (Vol. 13). New York: Harper.

Schwarzmantel, J. (2006). Republican Theory and Democratic Transformation. In I. Honohan, \& J. Jennings (Eds.), Republicanism in Theory and Practice (pp. 140-153). London: Routledge.

Smith, J. C. (2000). Smith \& Thomas: A Casebook on Contract (11th ed.). London: Sweet and Maxwell.

Sunstein, C. (2004). The Second Bill of Rights. New York: Basic Books.

Walzer, M. (1987). Interpretation and Social Criticism. Cambridge, MA: Harvard University Press.

Yeatman, A. (1997). Contract, Status and Personhood. In G. Davis, B. Sullivan, \& A. Yeatman (Eds.), The New Contractualism (pp. 39-56). South Melbourne: Macmillan Education Australia. 